BOSCHUNG, BREMMER (EDS.) - THE MATERIALITY OF MAGIC 


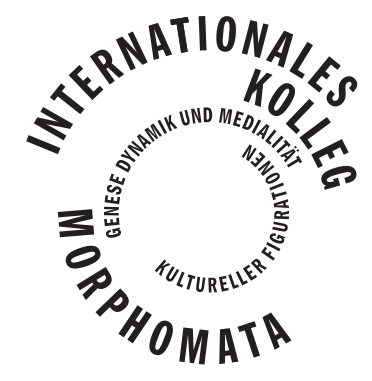

MORPHOMATA

EDITED BY GÜNTER BLAMBERGER

AND DIETRICH BOSCHUNG

VOLUME 20 
EDITED BY DIETRICH BOSCHUNG

AND JAN N. BREMMER

\section{THE MATERIALITY OF MAGIC}

WILHELM FINK 
GEFÖRDERT VOM

Bundesministerium

für Bildung

und Forschung

unter dem Förderkennzeichen 01UK0905. Die Verantwortung für den Inhalt der Veröffentlichung liegt bei den Autoren.

Bibliografische Informationen der Deutschen Nationalbibliothek: Die Deutsche Nationalbibliothek verzeichnet diese Publikation in der Deutschen Nationalbibliografie; detaillierte Daten sind im Internet über www.dnb.d-nb.de abrufbar.

Alle Rechte, auch die des auszugweisen Nachdrucks, der fotomechanischen Wiedergabe und der Übersetzung vorbehalten. Dies betrifft auch die Vervielfältigung und Übertragung einzelner Textabschnitte, Zeichnungen oder Bilder durch alle Verfahren wie Speicherung und Übertragung auf Papier, Transparente, Filme, Bänder, Platten und andere Medien, soweit es nicht $\ 53$ und 54 UrhG ausdrücklich gestatten.

(C) 2015 Wilhelm Fink, Paderborn

Wilhelm Fink GmbH \& Co. Verlags-KG, Jühenplatz 1, D-33098 Paderborn

Internet: www.fink.de

Lektorat: Jan N. Bremmer, Torsten Zimmer, Thierry Greub

Umschlaggestaltung und Entwurf Innenseiten: Kathrin Roussel

Satz: Andreas Langensiepen, textkommasatz

Printed in Germany

Herstellung: Ferdinand Schöningh GmbH \& Co. KG, Paderborn

ISBN 978-3-7705-5725-7 


\section{CONTENT}

JAN N. BREMMER

Preface: The Materiality of Magic 7

Abbreviations 21

JACCO DIELEMAN

The Materiality of Textual Amulets in Ancient Egypt

LAURA FELDT

Monstrous Figurines from Mesopotamia. Textuality, Spatiality and Materiality in Rituals and Incantations for the Protection of Houses in First-Millennium Aššur

JAIME CURBERA

From the Magician's Workshop: Notes on the Materiality of Greek Curse Tablets

JAIME CURBERA AND SERGIO GIANNOBILE

A 'Voodoo Doll' from Keos in Berlin's Antikensammlung

Appendix by JOCHEN VOGL and MARTIN ROSNER:

Lead Isotope Analysis of an Ancient Voodoo Doll

RICHARD L. GORDON

From Substances to Texts: Three Materialities of 'Magic' in the Roman Imperial Period

VÉRONIQUE DASEN

Probaskania: Amulets and Magic in Antiquity

ÁRPÁD M. NAGY

Engineering Ancient Amulets: Magical Gems of the Roman Imperial Period 
JAN N. BREMMER

From Books with Magic to Magical Books in Ancient

Greece and Rome?

JITSE DIJKSTRA

The Interplay between Image and Text. On Greek Amulets

Containing Christian Elements from Late Antique Egypt

JÜRGEN BLÄNSDORF

The Curse Inscriptions and the Materia Magica of the

Anna-Perenna-Nymphaeum at Rome

ANNEWIES VAN DEN HOEK, DENIS FEISSEL, JOHN J. HERRMANN, JR.

More Lucky Wearers: The Magic of Portable Inscriptions

PETER J. FORSHAW

Magical Material \& Material Survivals: Amulets, Talismans, and Mirrors in Early Modern Europe

OWEN DAVIES

The Material Culture of Post-Medieval Domestic Magic in Europe: Evidence, Comparisons and Interpretations

Notes on Contributors

Plates 
VÉRONIQUE DASEN

\title{
PROBASKANIA: AMULETS AND MAGIC
} IN ANTIQUITY

\begin{abstract}
A large number of jewellery items, in precious or cheap material, were used as charms in Antiquity, especially by children and women, attached to the body as pendants, earrings or bracelets. This paper reviews the typology and the meaning of the most common sets found in contexts of the Roman imperial period, looking for similarities and differences, continuities and discrepancies in other periods and regions. It analyses how amulets acted at different levels, medical, religious, and social, defining gender and status. It also examines how charms constructed a visual discourse on health, coming of age, and the life course in Antiquity.
\end{abstract}

\section{INTRODUCTION}

Long neglected by the mainstream of academic research because they are usually not very costly, nor elaborate, amuletic charms were ubiquitous in ancient daily life for at least three reasons, medical, social, and religious. First, medical because they served as protection against evil influences believed to be responsible for unexpected illness and death, bewildering infections and epidemics. Some amulets also aimed not just at protecting in a generic way, but at preserving or healing a specific part of the body. Second, social strategies are at work because amulets can characterise status and gender, as in Rome, where the gold bulla was allegedly reserved to freeborn elite boys. Third, amulets had religious functions and could be part of transition rites. The three levels often mingle, as most amulets combine defensive, social, and religious functions. All construct a visual discourse on health, coming of age and the life course in Antiquity. 
Like other objects relating to magical practices, such as magical gems, the study of amulets has expanded over the last years thanks to an increasing attention to the archaeological evidence, which is now abundant and diversified. It demonstrates the materiality of objects that used to be known only in iconography; some finds, such as the presence of bullae in Roman female jewellery, also reveal uses not mentioned by literary evidence.

I will discuss here a selection of charms relating to children and women, who owned many because they were the most vulnerable members of the community. Pregnancy and delivery were regular causes of female mortality. A wide range of sources record deaths in childbed. The situation must have been similar to that of the pre-modern era, where about $3 \%$ women died during delivery or in the following weeks, and they had repeated deliveries. Childhood was also a very hazardous time; about one in four babies died in the first year of life, and only about $50 \%$ of all neonates reached adulthood (i.e. the age of 18). In iconography, their special need for protection is visualised by amulets. Even divine children wear them, such as the plump bronze figurine of Harpocrates holding a hand to his mouth found in Augusta Raurica ( $1^{\text {st }}$ cent. AD) (fig. 1). ${ }^{1}$

The use of amuletic protections, however, was not restricted to children and women. Men also carried them, especially when facing dangers or in critical situations. I cite three cases from widely separate periods of ancient history. Plutarch records that when Pericles had fallen ill during the 'plague' of 431-27 BC, he was persuaded to wear an amulet. In keeping with his general dislike of 'superstition', Plutarch cites Theophrastus for the claim that Pericles was prevailed upon by women to do something he himself considered 'foolish':

Theophrastus in his Ethics [...] records this fact, that Pericles, as he lay sick, showed one of his friends who was come to see him an amulet (periapton) that the women had hung round his neck, as much as to say that he was very badly off to put up with such folly (abelteria) as that. ${ }^{2}$

1 Cf. the birth of Erichthonios with a chain of amulets in Attic vase-painting; e.g. on the attic red-figure calyx-krater, Richmond, Virginia Museum of Fine Art; Neils/Oakley 2003, 88 (fig.), 208, cat. 6.

2 Plutarch, Pericles, 38.2; transl. B. Perrin, Loeb. Cf. Pliny, HN 28.29 on two magistrates who used to wear little bags containing a remedium against ophthalmia. 
VÉRONIQUE DASEN: PROBASKANIA: AMULETS AND MAGIC IN ANTIQUITY $\mathbf{1 7 9}$

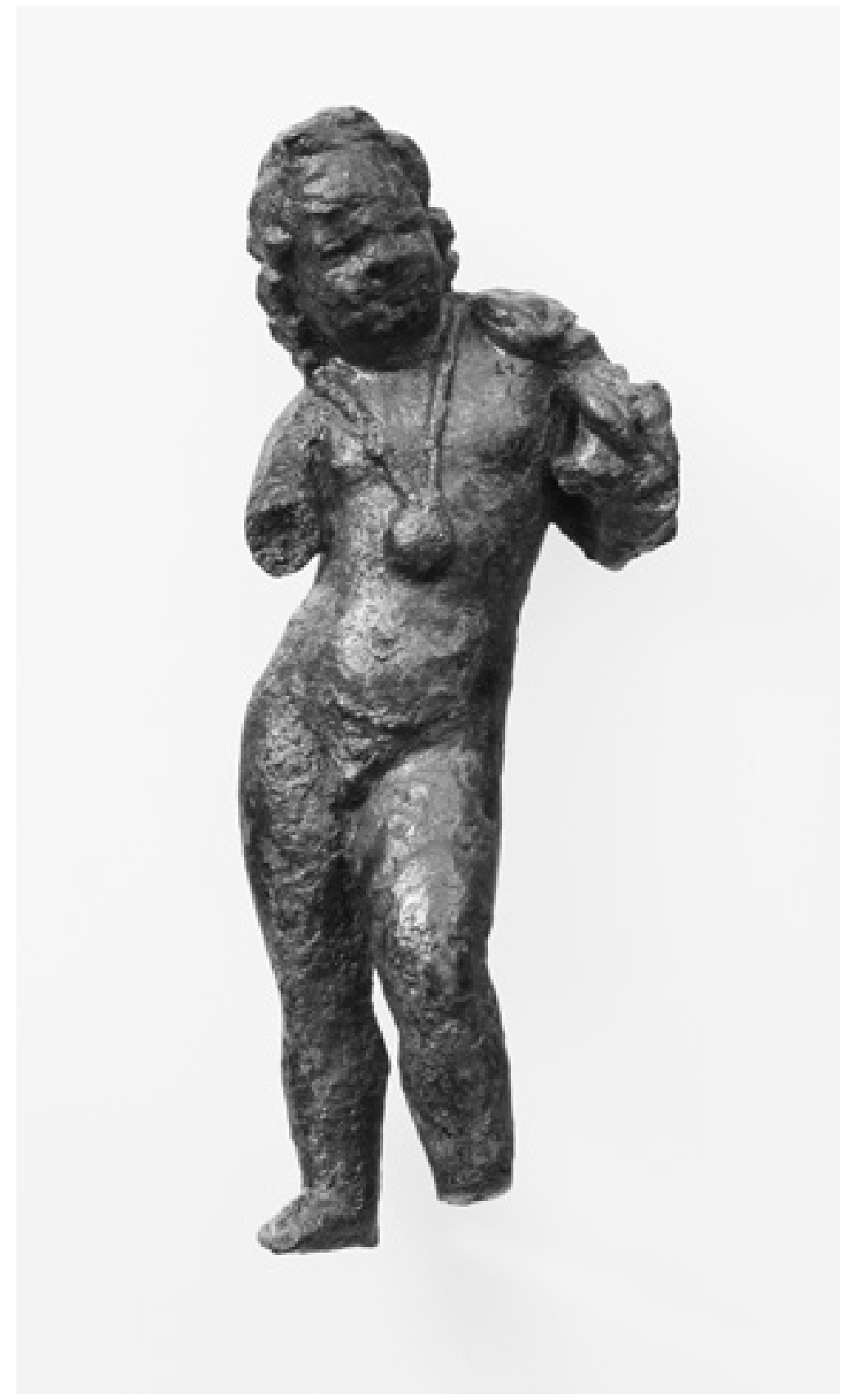

1 Bronze Harpocrates (H. $7 \mathrm{~cm}$ ). From Augusta Raurica, lower town, Reg. 17, C Augusta Raurica. 1987.003.C03258.1 
We are not told whether the amulet consisted of an item of jewellery, a gem, or some medicine wrapped in a little bag. In the first century BC, the Roman general L. Cornelius Sulla used to wear at war a small golden image (agalmation) of Apollo 'from Delphi', which was perhaps a religious token from a shop in the sanctuary:

There is also a story that Sulla had a little golden image of Apollo from Delphi which he always carried in his bosom when he was in battle, but that on this occasion he took out and kissed affectionately, saying: 'O Pythian Apollo, now that thou hast in so many struggles raised the fortunate Cornelius Sulla to glory and greatness, can it be that thou hast brought him to the gates of his native city only to cast him down there, to perish most shamefully with his fellow-countryment? ${ }^{3}$

It may have resembled the amuletic figurine of Apollo in hammered gold, with a loop in the back for suspension, now in the Derek J. Content collection (pl. 7 a, b). Finally, in late antiquity, the Cynic philosopher Asclepiades always travelled with a little silver figurine (argenteum breue figmentum) of the Dea Caelestis, which in $362 \mathrm{AD}$ he dedicated in the temple of Apollo at Daphne - thus inadvertently causing the fire that destroyed the temple. ${ }^{4}$

I will first define how the Ancients conceived the action of malevolent powers, and second review a series of common devices. I will focus on Roman material, looking for similarities and differences, continuities and discrepancies in other periods and regions, aware that many amulets were made of perishable material that disappeared archaeologically, but survive in iconography, such as the Heracles knot, nodus Herculaneus, the strings tied up around the wrist, ankle or thigh, sometimes with a pendant, perhaps of the type that still exists in modern Greece. ${ }^{5}$

3 Plutarch, Sulla, 29.6, transl. B. Perrin, Loeb. See Dölger 1934. Plutarch's Lives of Lysander and Sulla were written as negative foils in respect of the proper attitude to religion to those of Pericles and Q. Fabius Maximus.

4 Ammianus Marcellinus 22.13.3.

5 Cf. Wolters 1905; Saglio 1906, 87-88; Keyssner 1936, col. 807-809. A red cord on the wrist of children is described by John Chrysostom, Homilies on the Epistles of Paul to the Corinthians, 1.12.13. On strings with pendant at the thigh, Kreilinger 2007, 151-152; Dasen 2009b. 


\section{NAMING AND DEPICTING THE EVIL EYE}

Belief in the Evil Eye assigned a destructive power to the gaze due to envy or jealousy, called in Greek phthonos or baskania, in Latin fascinum, that arises from the view of happiness, beauty and prosperity. ${ }^{6}$ Plutarch explains that such gaze strikes like poisoned arrows and can harm, or even kill:

When those possessed by envy (phthonos) to this degree let their glance fall upon a person, their eyes [...] then assail that person as if with poisoned arrows. [...] What I have said shows why the so-called amulets (probaskania) are thought to be a protection against malice. The strange look of them (atopia) attracts the gaze, so that it exerts less pressure upon its victim. ${ }^{7}$

Atopia and geloia are thus appreciated because unusual or awkward shapes will distract the Evil Eye from its victim. This harmful power may not depend from the will:

[...] and in some cases even fathers have the Evil Eye, so that their wives will not show them their children nor allow the children to be gazed upon by them for very long. ${ }^{8}$

The extent of the damage caused by jealousy or dislike (zelos) and envy (phthonos) is impressive. Plutarch equates it with a public health problem. It is 'the most shameful disease (nosemata) and baneful plagues (kera), ruinous not only for private houses, but for the state as well. ${ }^{9}$

6 For a review of the literary sources, see e.g. Bernand 1990, 92-105; Clerc 1995, 88-97; Rakoczy 1996.

7 Plutarch, Table-Talk, 681E-682A; transl. P. A. Clement, H. B. Hoffleit, Loeb. The shaping power of the gaze also explains the phenomenon of 'maternal impressions' on the fetus; Dasen 2009a.

8 Plutarch, Table-Talk, 682A. Full discussion of the literary texts: Alvar Nuño 2012, 87-157.

9 Plutarch, Table-Talk, 484 C; see also 787 C. The most critical moments are associated with pleasure, especially eating, as well as with the display of wealth and success that attracts envy. On table manners aiming at avoiding troubles, see pseudo-Aristotle, Problemata 20.34 (926b21-31). 

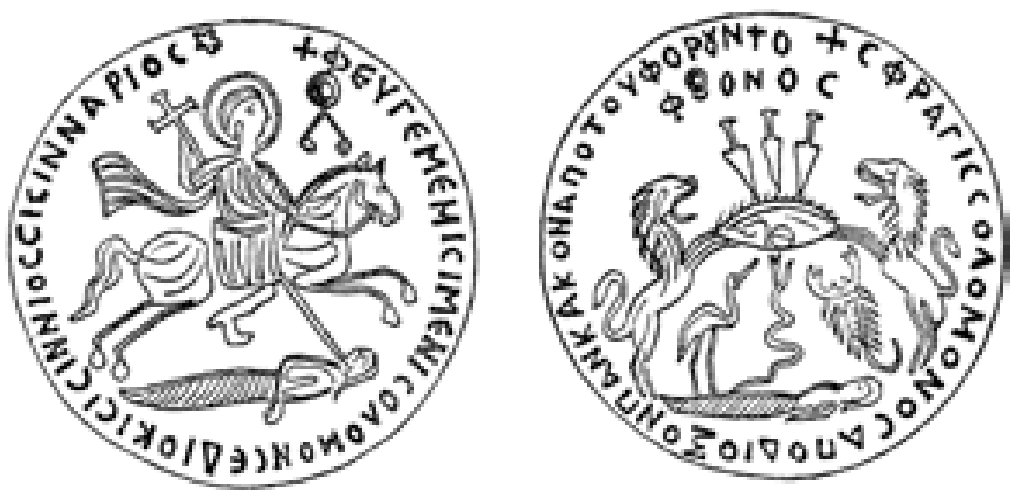

2a-b Silver-plated copper. Schlumberger collection 1

Material damages on objects too can be caused by envy, and Pollux explains how potters nailed geloia on their furnace to protect the firing process. $^{10}$

The protective image of eyes and gaze appears very early in various media in the ancient Mediterranean world, ${ }^{11}$ but an amuletic device figuring the Eye was developed only in the Hellenistic period, and does not become common until the Roman Imperial period. It is always a human eye, attacked by various animals and weapons. It is often found on small personal objects, such as a gold disc in the British Museum (pl. 8) ${ }^{12}$ that can be compared with a silver pendant from a child's cinerary urn in Aventicum $^{13}$ (160-200 AD). The Eye is encircled by eleven destructive elements: offensive weapons (thunderbolt, trident, club), apotropaic animals (two birds, dog, lion, scorpion, snake), a figure in a vessel (?), and a winged (?) phallus. Similar depictions occur in domestic contexts, such as the famous mosaic at the entrance of the so-called 'House of the Evil Eye' in Antioch (early $2^{\text {nd }}$ cent. AD) $)^{14}$, on funerary monuments, such as

10 Pollux, Onomasticon, 7.108. Cf. n. 32 below on the phallus in a bakery at Pompeii.

11 See e.g. in Egypt Herrmann/Staubli 2010, no 72, 124-29. On Greek vessels, K. Karagianni in Merkouri 2010, 33-42.

12 Engemann 1975, 26, pl. 11c. See similar devices in Engemann 1975, 26, fig. 2. Good survey of the archaeology in Alvar Nuño 2012, 159-233.

13 Castella et al.1999, 313-4, no 1810, pl. 172.

14 The Evil Eye is attacked by weapons (trident, sword), animals (scorpion, snake, dog, leopard, raven), and the phallus of the dwarf (possibly also little 
the stela of Geminius Saturninus at Auzia in Roman Africa, ${ }^{15}$ in public and religious places, such as the entrance pavement of the Basilica Hilariana in Rome. ${ }^{16}$

On a series of late antique gems and Byzantine pendants, the Evil is personified by a female demon, lying on the ground, and speared by a rider, called Solomon, after the biblical king who was believed to be an expert in magic and exorcism, as on the Schlumberger medallion (fig. 2a). ${ }^{17}$ This polyonymous malevolent female figure - Gello, Gyllou, Alabasdria, Abyzou, Obyzouth - is made responsible for the death of pregnant women and children:

I am called among men Obizuth; and by night I sleep not, but go my rounds over all the world, and visit women in childbirth. And divining the hour I take my stand; and if I am lucky, I strangle the child. But if not, I retire to another place. For I cannot for a single night retire unsuccessful. For I am a fierce spirit, of myriad names and many shapes. ${ }^{18}$

She belongs to the category of 'the reproductive demon', ${ }^{19}$ governing sudden illnesses hard to explain that strike parturient women and infants, such as eclampsia, puerperal fever and neonatal death. Aitiological stories explain the action of these frightful female demons. They are believed to be human women who failed to complete their reproductive cycle and turned into evil spirits, stealing and killing the offspring of more successful mothers, such as Lamia who became insane because she bore many children to Zeus, but lost each baby soon after birth. All these demons turn into 'vampires' that feed on young children and women, whose main protection are specialised amulets carried on the body. Most

phalluses on top of the dwarf's head); Levi 1947, 28-34, pl. IV; Engemann 1975, pl. 10 a; Dunbabin/Dickie 1983, pl. 8 a; Clarke 2007, 64-67, fig. 22.

15 Engemann 1975, 29-30, pl. 13 b, d.

16 Engemann 1975, 28-29, pl. 11 a, b.

17 Schlumberger 1892, 74, no 1 (fig.); Engemann 1975, 25, fig. 1; Faraone 2012, 74-75, fig. 5.3. On this type of amulet, Spier 1993.

18 Testament of Solomon 58, transl. F. C. Conybeare, 'The Testament of Solomon', Jewish Quarterly Review 11 (1899) 30.

19 For the expression, Johnston 1995. On the demon and its post-antique afterlife, Barb 1966; Sorlin 1991; Cusumano 2008. On the threat of Mormo, see also Patera 2005. 
likely, the power of the trampling motif was not limited to the protection of women and children. Late antique gems are inscribed sphragis theou, with the double meaning 'god's seal' and 'god's medicine', suggesting the wide range of action ascribed to them. ${ }^{20}$ The reverse of the Schlumberger medallion (fig. 2b) equates the power of the demon with that of the Evil Eye. Above the prostrate woman, the Evil Eye, named Phthonos, Envy, is being attacked by five animals (lions, ibis, snake, scorpion), and three daggers. ${ }^{21}$

Evil power is also personified by a male figure that can interchange with the picture of the malevolent eye. It depicts Phthonos, Envy, as a man strangling himself, demonstrating the destructive might of envy. On a gold pendant from Cyprus (ca 100-200 AD) ${ }^{22}$, he holds both hands to his throat (pl. 9), like Livor in the Underworld: 'there jealousy which strangles herself with both hands (hinc angens utraque manu sua guttura Liuor)'.$^{23}$ Like the Evil Eye, the man is attacked by animals in more complex scenes. This image of Phthonos is found in different contexts, mostly private, such as pendants for personal protection, or on pavements for the protection of the house. ${ }^{24}$ Variants depict emaciated persons tearing open their belly, visualising the extreme feelings caused by unrelieved envy. ${ }^{25}$

20 On the double meaning of the term sphragis, Dasen 2011. Two byzantine amulets are inscribed with male personal names, suggesting that Gyllou could harm men as well; Spier 1993, 38 and 43.

$21 \mathrm{Cf}$. the famous fresco on the walls of the Bawit monastery (6th cent. AD) where the rider, named Sisinnios, spears the demon Alabasdria, topped with the Evil Eye attacked by opponents; Engeman 1975, 39-40, fig. 10.

22 Dunbabin/Dickie 1983, 22, pl. 4c. The pendant contains calcite, a carbonate mineral. I am grateful to Th. Kiely for this information.

23 Silius Italicus 13.584, transl. J. D. Duff, Loeb.

24 Dunbabin/Dickie 1983; Slane/Dickie 1993, 494-7. On the function of phthonos figurines, see also Jeammet 2011.

25 The notion of choking or bursting out of jealousy is common in Greek and Latin literature and inscriptions; cf. Martial 9.97 (rumpere); Lucian, Timon the Misanthrope, 40. See the sources collected by Slane/Dickie 1993, 495-97, esp. n. 82 and 85-86. 


\section{NAMING AMULETS}

The main terms express the idea of tie because an amulet is primarily an object or substance that you have 'on you' (habere secum), attached to the body, usually around the neck, the thigh, the ankle, or the wrist. Physical contact is essential in order to transmit the properties of the charm to its wearer. In Greek, amulets are thus called periammata, periapta, in Latin, ligatura or alligatura ('what is attached around'). Some terms refer to their medico-magical qualities. In Latin, remedia means 'remedies', praebia, 'providing protection':

Praebia, 'amulets', from praebere 'providing', that he may be safe, because they are prophylactics to be hung on boys' necks, in collo pueris. ${ }^{26}$

Other terms describe the shape of the amulet, such as fascinum for the phallus, lunula for the moon-shaped pendant, or bulla for the famous Roman gold container.

\section{GROWING HEALTHY}

Charms often combine the power of the material, such as gold, amber or animal teeth, and of crafted shape, such as the lunula. Some define the social and gendered identity of its wearer and relate to transition stages characterised by specific biological changes, such as teething for infants and menstruation for girls. They are often found in tombs, but aimed primarily at protecting the living.

\subsection{THE PHALLUS AND THE CLUB}

The best-known charm in the Roman period is the phallus, which was used by all, from infant to imperator, as Pliny the Elder reports. ${ }^{27}$ Varro explains that its efficacy is associated with obscenity:

26 Varro, On the Latin Language, 7.107, transl. R. G. Kent, Loeb.

27 Pliny, NH 28.39: 'And yet the baby (infans) is further under the divine protection of Fascinus, guardian not only of babies but of generals (imperatores) [...] hanging under the chariots of generals at their triumphs he defends them as a physician from jealousy (medicus inuidiae)' (transl. W. H. S. Jones, Loeb). 
Perhaps it is from this that a certain indecent object (turpicula res) that is hung on the necks of boys (pueris), to prevent harm from coming to them, ne quid obsit is called a scaeuola, on account of the fact that scaeua is 'good'. ${ }^{28}$

Most phallic devices are in bronze, but other materials are used, such as gold or amber. ${ }^{29}$ Pliny the Elder details the curative and apotropaic value of gold. The incorruptible metal protects against all kind of aggressions:

Gold is efficacious as a remedy (remedium) in a variety of ways, and is used as an amulet for wounded people and for infants to render less harmful poisonous charms (ueneficia, uis malefica) that may be directed against them. ${ }^{30}$

Few images show a person with a phallic charm; ${ }^{31}$ most depict the phallus alone, or as part of fantastic figures, in public and private spaces. The protective function of the phallus is usually related to the virile and regenerative power of an erected phallus. In Pompeii (VI, 6, 18), the well-known plaque with an erected phallus inscribed Hic habitat felicitas, was placed above an oven. One can assume that the image promoted two actions: averting demons from damaging the bakery, as did potters for their kilns, and inciting the bread to rise. ${ }^{32}$ In most examples, however, the emotion, shame or laughter, created by obscenity is chiefly at work, diverting the envious gaze of onlookers. Another aspect, often neglected, also explains the efficacy of the device: the phallus is equated with a weapon in collective imagery. Greek and Latin sexual vocabulary have explicit weaponry metaphors for male sexuality. In numerous inscrip-

28 On the Latin Language, 7.97, transl. R. G. Kent, Loeb.

29 On gold and coral phallic pendants and rings, see e.g. Johns 1982, 63 and fig. 10; Johns/Wise 2003. Three amber phallic pendants were part of a set in the tomb of a child in Poitiers; Brives 2008, 165, nos 11-13, fig. 2. Specifically on the phallus types, see Alvar Nuño 2012, 162-86.

30 Pliny, $H N$ 33.25.

31 An Etruscan bronze statue in Kassel shows a boy standing holding a bird; a typical male set is suspended to a string across his chest: a phallic amulet, an oil flask, and a strigil; Bieber 1915, 70, fig. 214.

32 Cf. Clarke 2007, 72-73, fig. 28, who reads a pun in the word felicitas 'Here lives fertility/happiness together'. 
tions and images, the phallus threatens to violate the envious sexually. ${ }^{33}$ In the Priapea, Priapus protects the garden against thieves by inflicting them a sexual penalty, poena, explicitly using his erect phallus instead of a club or a sickle. ${ }^{34}$ The association is also reflected by verbal puns. In Greek, the phallus can be addressed as a club, skutale or rhopalon. ${ }^{35}$ It is thus connected with another device, the club of Heracles, which is likewise found very frequently as a protective device in both public and private contexts. ${ }^{36}$ Such associations are more than metaphorical. ${ }^{37}$

In an amuletic context, I thus regard Heracles' club as interchangeable with the phallus as a weapon against the Evil Eye. Their similar metaphorical meaning may explain why women usually do not wear phallus amulets (at least not ostensibly), but enjoy clubs as earrings or pendants. ${ }^{38}$ The hero's attribute is a more suitable ornament, with a similar generic protective meaning, and an added value for women. A sexual and erotic connotation is at work, as Heracles is a renowned lover, who fathered many children; his unusual intimacy with women is exemplified by his servitude in the house of Omphale, where, according to Ovid, he was forced to wear women's clothes and hold the wool while Omphale and her women spin. ${ }^{39}$ Heracles was hence a most appropriate guardian of seductiveness as well as of reproduction. ${ }^{40}$ This competence of Heracles explains the use of a nodus Herculaneus for the bride's girdle in Roman rites of marriage. According to Festus, the bridegroom loosed it in the hope of being as blessed with children as Heracles, who had 70 children. ${ }^{41}$

33 See the list of monuments collected by Slane/Dickie 1993, 488-94.

34 Corpus Priapeorum, 11; see also 9 and 20.

35 Several words are used in Latin, such as telum; see Adams 1982, 19-24.

36 Bruneau 1964 (phallus and clubs).

37 Cf. Dictionnaire de l'Académie françoise, II, Paris, 1798, 155 ('nerf de boeuf'). The English word 'pizzle' (derived from the Middle Dutch peserik, sinew, string, whip of bull's hide, pizzle) means both a bull's penis and a whip made of a dried penis. The Oxford English Dictionary cites a letter by Sir Walter Scott to Robert Southey in 1814: 'The wholesome discipline of a bull's pizzle and straitjacket'.

38 See the catalogue of club pendants and earrings collected on German sites by Werner 1966.

39 Ovid, Heroides, 9.53-118.

40 On Heracles and Omphale in a magical context, Dasen 2008.

41 Festus 55.18 Lindsay, s.v. cingulum; see Bettini 1998, 114-120. 


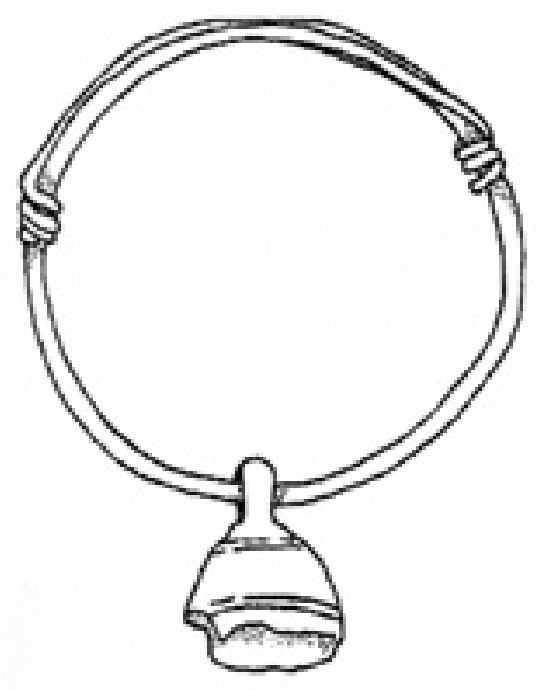

3 Silver bracelet with bell (L. $5 \mathrm{~cm})$. Poitiers

Heracles' club had a more specific apotropaic meaning for children. Heracles is the model of the child surviving fatal dangers in early childhood, as demonstrated by his strangling the snakes sent by Hera against him as an infant. A sexual reference too is not unlikely. The club may have protected children against sexual assaults, just like the bulla, of which Plutarch says:

Or the Romans of early times [...] strictly refrained from (sexual relations with) boys of free birth; and that they might not be in any uncertainty, even when they encountered them unclad, did the boys wear this badge? Or is this a safeguard to insure orderly conduct, a sort of bridle on incontinence? ${ }^{42}$

A bulla and a club pendant, both in gold, are thus meaningfully combined as a set in the tomb of a boy in Saint-Fréjus ( $1^{\text {st }}$ cent. AD) (pl. 10a). ${ }^{43}$

42 Roman Questions, 101, transl. F. C. Babbitt, Loeb. The recent commentary by J. Scheid does not discuss either issue.

43 Bel 2012, 210 and 213, fig. 18 (belonging to a child two-five years old). The amber set from the child's grave in Poitiers, included a club with the three phallus; Brives 2008, 165, no 10, fig. 2. 
Plautus alludes to rattling devices, crepundia, at the neck of children. ${ }^{44}$ Such necklaces perhaps incorporated a little bell that is found only with children, of both sex, probably as a noisy protection against evil..$^{45}$ Bells were often attached to bracelets, such as the one found in a child's tomb in Poitiers ( $2^{\text {nd }}$ cent. AD) (fig. 3$) .{ }^{46}$ Some bronze or gold items have devices and inscriptions wishing good luck and averting evil, such as small bronze bell in Budapest. ${ }^{47}$ John Chrysostom (347-407 AD) still complains about their use:

What shall we say about the amulets, periapta, and the bell, kodon, which are hung upon the hand, and the scarlet woof, and the other things full of such extreme folly; when they ought to invest the child with nothing else save the protection of the Cross. ${ }^{48}$

\subsection{THE LUNULA AND THE POWER OF THE MOON}

Another common amulet, in Greek as in Roman contexts, has the shape of the crescent moon, usually made in bronze or silver. In his Lexicon (6th century AD), Hesychius describes it thus: 'Selenis, an amulet (phylacterion) at the neck of children (paides)'. Also called in Greek meniskos, in Latin lunula, it is found alone or associated with other charms. Iconography as well as archaeological finds confirms its regular use by children, women... and animals, since ancient Egypt. ${ }^{49}$ Adult men do not seem to have worn them. In Greece, a few items go back to the Mycenaean period ( $13^{\text {th }}$ century BC), but most date to the Principate. ${ }^{50}$

44 Plautus, The Braggart Soldier, 1399: quasi puero in collo pendeant crepundia. 45 Little bells are also part of phallic mobiles or tintinnabula, suggesting their value as evil averters. See e.g. Johns 1982, 67-71, fig. 52, 54; Clarke 2007, 69-70, fig. 25; G. Bapheiadis in Merkouri 2010, 62, figs 13-14.

46 Brives 2008, 163, nos 2-3, fig. 1. See e.g. the bronze bells in Aventicum; Castella et al. 1999, 330, nos 1793 and 1794, pl. 171; Dasen 2003, 287, pl. IV, fig. 11. In Arras, the bell was attached to a chain with a phallic lunula; Jelski 1984,264 , no 8 , pl. I.

47 Nagy 1992 with a list of extant clay, bronze and gold bells for the living and the dead.

48 Homilies on the Epistles of Paul to the Corinthians, 1.12.13.

49 On animals' amulets, see Wrede 1975.

50 On their chronological distribution, Wrede 1975. Cf. the silver lunula from the cremation urn of a 3-4 years old child (125-130 AD); Dasen 2003, 286, pl. IV, fig. 8. 
The repeated - and stereotyped - complaints by various Church fathers reveal how widespread their use was, in particular for children. In the fourth century, Gregory of Nazianzus laments in his speech On Baptism:

You have no need of amulets, periammata, and incantations, epasma$t a$, along which the Evil One makes his way into the minds of the simpler folk, stealing for himself the honour that belongs to God.

The scholium comments:

Periammata: the bits of colored thread round wrists, arms, and necks; and moon-shaped plates of gold, silver or cheaper material, which foolish old women fasten upon infants. ${ }^{51}$

The lunula most likely placed children and women under the protection of Artemis-Selene who controls the growth, maturation and procreation of humans as well as of animals. ${ }^{52}$ The image of the moon had a more specific meaning for women. The monthly menstrual cycle (katamenia, menses) was believed to be synchronized with that of the moon, symbolised by the lunula..$^{53}$ The crescent-shaped pendant thus governed the regular evacuation of excess of blood, regarded as a condition for the maintenance of health and for becoming pregnant, the ultimate aim of women's lives. It probably also watched over the onset of menarche, an expected event in the lives of girls. In Augusta Raurica, an adult woman wore two silver earrings in the shape of stylised clubs, averting diseases as well as protecting her sex appeal, and a glass bead string with a silver lunula pendant aiming at preserving a healthy humoral balance, a perfect set displaying her conscious control over her body (pl. 10b). ${ }^{54}$

51 Migne PG 36, 907 B-C, transl. Bonner 1950, 3-4.

52 Some are combined with a phallic device; Jelski 1984, 264, no 7, pl. I.

53 E.g. Aristotle, History of Animals, 8.2 (582a 34); Dean-Jones 1994, 94-101. For its use in ancient Near East and Egypt, esp. by breastfeeding women, see e.g. Wrede 1975, 249-50.

54 Swift 2003, 341 and 345, fig. 5. 


\section{AVERTING AND CURING DISEASES}

\subsection{TEETHING}

Specific sets are associated with teething, the first major step in early childhood, that occurs at about six or seven months. Teething implies change of food and change of status, as the infant progressively takes place in the life of the community by sharing its food. This process lasts until weaning is achieved, at about two or three years. Medical writers were very concerned with changes inducing potential imbalance and sickness, and they mention the dangers of this critical period. A Hippocratic treatise devoted to teething, On Dentition, reflects the importance credited to that stage. ${ }^{55}$ The Hippocratic Aphorisms (5th cent. BC) detail the most feared symptoms: ulceration of the gums, fevers, spasms, and diarrhoeas, 'especially when cutting the canine teeth'. The fragile humoral balance of small children was threatened by these troubles that can quickly degenerate with dramatic consequences. Harmless disorders, explains Celsus ( $1^{\text {st }}$ cent. BC/AD), such as aphthous ulcers ('thrush'), are innocuous for adults but can be lethal for sucklings as they hamper proper feeding. ${ }^{56}$

The idea that teeth can 'kill' is proverbial in many languages: 'Soon todd [toothed], soon with God', warns a seventeenth-century proverb. ${ }^{57}$ This commonplace lasted until the nineteenth century. In 1836, a Berlin medical doctor, W. Andresse, wrote a book in order to deconstruct it, reporting that teething was indeed a cause of mortality, but because the real diseases, unrelated to dentition, were not treated. ${ }^{58}$ The teething process was an object of great attention in folk medicine. P. Gaillard-Seux collected about 23 amulets for the teething of infants in Greek and Latin authors of the Roman Imperial period. ${ }^{59}$ Alone Pliny the Elder's Natural

55 On dentition (Littré VIII, 542-549), dating to the Common Era.

56 Celsus, On Medicine, 6.11.3.

57 Cf. the French expression 'mourir des dents', in German: 'An den Zähnen sterben'.

58 Ueber das schwere Zahnen der Kinder, Reutlingen, 1836, 79-80: 'Ich habe in der That gefunden, dass in den meisten Fällen wirkliche Krankheiten vorhanden waren, die [...] mit den Zähnen in keiner Weise in Verbindung standen (...) Es war daher meine Aufgabe, bei dieser Arbeit das allgemein herrschende Vorurtheil über das schwere Zahnen gründlich zu widerlegen'. 59 Gaillard-Seux 2013, 196, note 30. 
History lists about a dozen amulets for averting or relieving the feared symptoms. Most remedies use real teeth and function according to sympathetic magic. The teeth of a range of strong or symbolically qualified animals are much valued, such as wolf's, dog's, mole's and dolphin's teeth, usually attached to the body (adalligati) to ease the process. ${ }^{60}$

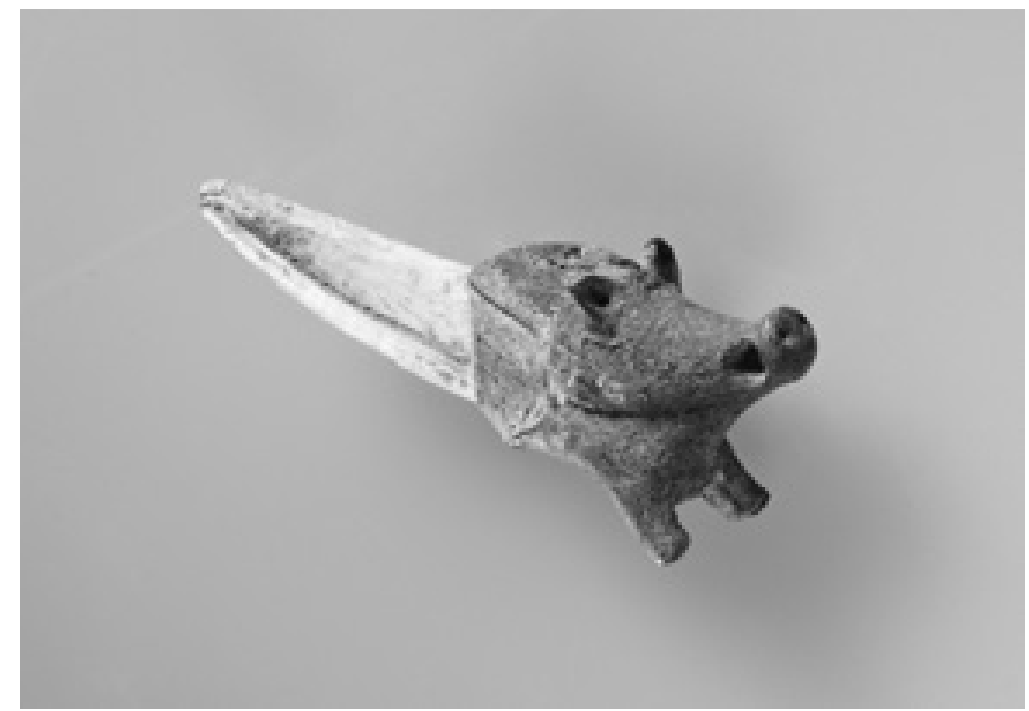

4 Boar tusk (tusk: L. 3,2 cm; boar: 3,2 cm). Bruxelles, Musées royaux d'Art et d'Histoire R. 1054

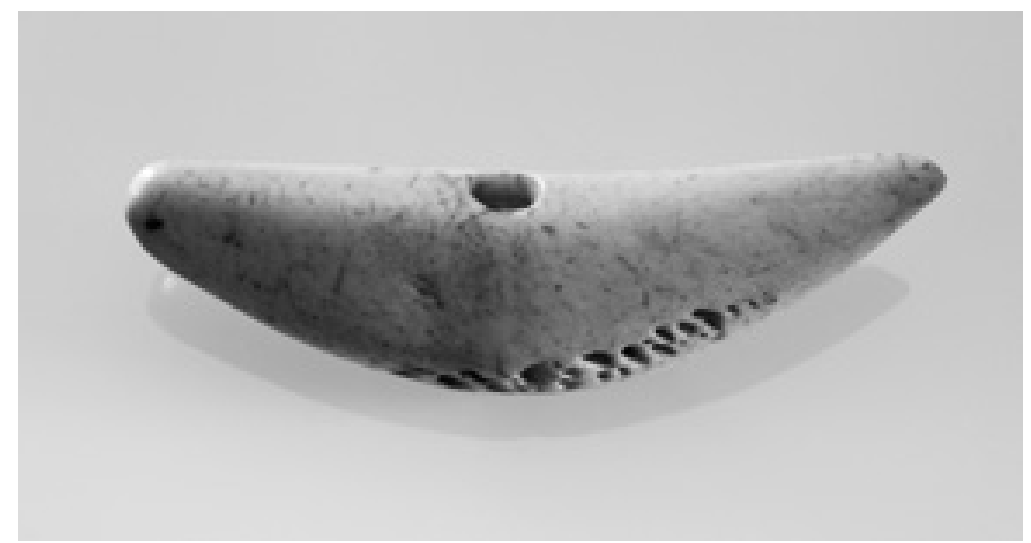

5 Bone imitating a tooth (L. 6, 6 cm). Augusta Raurica 1973.550 
Tooth-ache of adults also benefits from teeth's power. ${ }^{61}$ The aesthetic of the amulet could add to its efficacy, such as the wild boar tusk kept in Brussels, embellished with a bronze boar head (fig. 4$)^{62}$ or a lion's tooth set in gold from Augusta Raurica (pl. 11a).

In Roman Gaul, parental anxiety is displayed by the large number of charms from the graves of children in the crucial period of alimentary change, between six months and about three years, at the time of weaning. ${ }^{63}$ Various types of animal teeth, worn as pendants, are found. ${ }^{64}$ The need for teeth seems to have led to the production of artificial ones, such as the bone pendant imitating a tooth from Augusta Raurica (fig. 5) ${ }^{65}$ Animals incorporated in the set may express a similar protection. Our 'little mouse', who comes into action when the milk teeth fall out was perhaps replaced by the hare because of the impressive teeth of the rodent; the animal is often present in the form of little pierced plaques included in a necklace, often in amber, possibly for its medical qualities in the teething process.$^{6}$ Parts of the hare are also used as remedies. Hare's brain was prescribed for rubbing the gum of infants to ease dentition,

60 Pliny, $H N 28.257$ (wolf); 28.258 (horse), 30.20 (living mole), 30.21-22 (dog); 32.48 (dolphin). The teeth of some animals, such as the wolf and the dolphin, also prevented anxiety attacks in children.

61 Pliny, HN 28.95 and 181; 30.21-22 (dog, horse, hyena, snake).

62 De Meester de Ravestein 1884, 312, no 1054. I thank C. Evers for providing me this information, and the photograph.

63 Cf. the table showing the distribution and type of objects according to the age of the child in Bel 2012, 205, fig. 9.

64 A beaver's tooth is reported by Bel 2012, 202, fig. 13 in the grave of a child (one-four months old), with several amulets, including a lunula and a gold phallic pendant); see also Bel 2012, 206, on a fossilised shark's tooth in Nîmes.

65 See e.g. the false tooth from the tomb of a one-year old child in SainteBarbe, Marseille; Dasen in press, fig. 6a (associated with a dog's tooth, fig. 6b).

66 Brives 2008, 162, no 6, fig. 2. On this popular legend in France and Switzerland, Loux 1981, 54-57. See also the amber rabbit and the fish (a dolphin ?) with animal teeth in a six-month old baby in Nîmes; Bel 2012, 209, fig. 14; Dasen in press, fig. 5. On the marked association of amber with the infantile population, see Swift 2003, 342-3 and 345. On its medical and apotropaic qualities, see e.g. Causey 2011. 
gums could be scarified with a needle-like bone from its body, whereas hare's rennet was injected in the ear in order to relieve toothache. ${ }^{67}$

\subsection{REMEDIES' CONTAINERS}

The word phylacterion, phylacterium, can designate a container for phylacteries, inscribed with a prayer against fever or other diseases on a papyrus or metallic sheet, made of silver or gold. It could also contain medicine.$^{68} \mathrm{~A}$ sealed silver tube found in the tomb of a woman in Judaea thus contained a remedy made of $50 \%$ haematite (early $3^{\text {rd }}$ cent. AD) ${ }^{69}$ Beside the famous gold bulla, which I have already mentioned, which was reserved to elite freeborn boys (see further below), bronze globular lockets fall into this category. They were worn by children, male and female, as well as by adult females. Some texts refer to their use as containers of remedia. For example, a recipe recorded by Marcellus Empiricus ( $5^{\text {th }}$ cent. AD) recommends extracting the eyes of a green lizard with a copper needle and placing them in a bulla or gold case in order to protect the wearer from eye diseases. ${ }^{70}$

Archaeological finds confirm that lockets enclosed curatives. In Pannonia, the bronze bullae studied by Magdolna Szilágyi were not reserved to boys. All those found at Intercisa and Aquincum came from the tombs of women and children, none from that of an adult male. ${ }^{71}$ Most lockets contained various vegetal products wrapped in textile remains, such as a dried grape, thorns of a rose, and medicinal plants, such as coriander (Coriandrum sativum), aniseed (Pimpinella anisum), and snap-dragon (Antirrhinum majus). One bulla made of bronze contained an inscribed silver lamella and a coin. ${ }^{72}$ The presence of dried grapes may be associated with magico-medical practice. In Greek medicine, the word for

67 Pliny, Natural History, 28.178-179; 259.

68 For phylacteries, see also Dieleman, this volume.

69 Ilani et al. 1999.

70 The Book of Medicaments, 8.50; the same procedure in relation to the lizard's liver, ibid. $22.41=$ Heim 1892, 483, no.71. See also Macrobius, Sat. 1.6.9; Palmer 1989, 66-67. Cf. the powers attributed to the green lizard in magical recipes and magical gems; Nock 1931/1972; Gaillard-Seux 1998.

71 Szilágyi 2004, 17-18, table 4: of 28 bullae from Pannonian graves, 18 belonged to children, 9 to adult women; see the similar observation by Swift 2003, 345 .

72 Kotansky 1994, 91-92, no 20. 
bunch of grapes, staphule also designates a swollen uvula ${ }^{73}$, a metaphor used in magical formulae. Marcellus Empiricus thus prescribes placing a grape on the throat, while reciting: uиa uuam emendat, 'the grape cures the uvula' ${ }^{74}$ Recently, a small bulla made in bronze was found in a collective tomb in Hierapolis (Phrygia); it contained a small lacteal tooth (first-seventh century AD). ${ }^{75}$

The history and function of the gold bulla, which could also contain remedies, must be distinguished from that of bronze bullae. Ancient authors associate the precious jewellery with social and gendered identity because only freeborn, and originally elite boys, could wear it as a token of virile courage. ${ }^{76}$ It was also a token offered to the Lares at puberty, which could vary between 14 and 17 years old, marking the passage to adulthood of boys who passed from the status of puer to iuvenis and took the toga virilis. According to R. E. A. Palmer, ${ }^{77}$ the gold bulla became a regular attribute of elite children in the mid-Republic. In the Augustan period, the custom was appropriated by freedmen families as a visual sign of social and familial success in funerary iconography..$^{78}$ The chronology and the modalities of its use, however, needs to be re-examined in the light of both written and archaeological sources. Very few gold bullae come from a funerary context (pl. 10a).$^{79}$ Is it because it was a costly familial token, transmitted from father to son, which would generally be transmitted to another child if its wearer died?

73 Hippocrates, Prognostic, 231.30 (Littré 2.177-81).

74 Marcus Empiricus, The Book of Medicaments 14.26 = Heim 1892, 486, no.80. Cf. P.Laur III 58, a third-cent. AD charm in which the Greek word staphulotomos, 'cutting the uvula', has been subjected to serial reduction in each of 12 lines; see Daniel/Maltomini 1990, 1: 3-6 no.1; also Faraone 2012, 64 fig.4.5.

75 Tomb 163d, belonging to a Jewish family according to the inscription. Unpublished. I thank Caroline Laforest, Dominique Castex et Francesco D'Andria (Mission archéologique italienne de Hiérapolis) for providing me this information.

76 Cf. Pliny, $H N$ 33.4; Plutarch, Roman Questions, 101.

77 Palmer 1989; Goette 1986.

78 See e.g. the funerary relief of the Augustan period illustrated in Dasen 2003, pl. III, fig. 6.

79 See above n. 42, the context of the bulla from Fréjus. See also e.g. the list of bullae found in Roman Gaul by Péchoux 2010. 


\section{RITES OF PASSAGE}

Amulets also construct a discourse on growing up that was not perceived as a continuum: the process was composed of steps that successively accomplished full integration into the community, often marked by ritual acts, which may in turn be associated with amuletic charms. Greek sets are the most explicit evidence for this. They compose a relatively stable iconographic vocabulary relating to coming of age; a good example is offered by a string of twelve gold charms from the necropolis of Akanthus in northern Greece (pl. 11b) ${ }^{80} \mathrm{~A}$ number of items on this string refer to the maturation of girls, such as the pomegranate, associated with Kore/ Persephone, and the tortoise, perhaps here an emblem of Aphrodite, alluding to the modesty prescribed for women, or as an attribute of Hermes, the patron of children..$^{81}$ The tortoise also averts magical spells, says the Homeric Hymn to Hermes. ${ }^{82}$ The double axe and the open hand, however, are found with children of both sexes and may express strength and divine protection..$^{83}$ The Silen's head may assume the function of the phallus, which is absent from Greek charms, with the added dimension of the Silen's guardian role as paedogogue. The gold knucklebone is particularly interesting, since it could allude to play, characteristic of childhood, but also to the divinatory dimension of the play, determining the fate of the child. ${ }^{84}$ It is striking to find the equivalent of the concept in Roman children's graves; a regular playing die, not a charm to hang, is often associated with juveniles, most likely with the same polysemic connotations of play, fate, and reference to the status of childhood, when labour is not required of one. ${ }^{85}$

80 Ziva 2009, 33, fig. 19. I thank B. Tsigarida for providing me this photograph.

81 See a similar bone set from the tomb of a girl in Abdera, Papaikonomou 2006, pl. 36, 2, and in a silver necklace from a funeral pyre in Thasos; Sgourou/Agelarakis 2001, 343-346, figs 29-33 (Silen's head, lion's head, double axe, tortoise, amber knucklebone, frog).

82 The Homeric Hymn to Hermes, 37-38. Repeated e.g. by Pliny, HN 32.33, adding the value of its flesh against all poisons.

83 Cf. the value of the open hand and clenched fist (with fica) in Egyptian amulets, Herrmann/Staubli 2010, no 73, 130.

84 On knucklebones in children's tombs, Carè 2012.

85 E.g. the small dice in the child's grave in Poitiers; Brives 2008, 165, fig. 2, no 16 . 
Similar amuletic sets are represented in vase-painting. Necklaces with charms are depicted on vessels that may have contained the actual jewellery, such as the pyxis in the Benaki Museum (fig. 6) (330-320 $\mathrm{BC}$ ). The front depicts a luxurious necklace with a double row of pendants and wedding earrings on the side, the back shows a string with fourteen amulets. For A. Ziva, the items evoke a premature death before marriage, with insects such as the cicada alluding to death and rebirth. However, a number of devices relate to the protection of the living, such as the apotropaic eye, the crescent-shaped meniskos for regular growth and menstruation, the embolon, attribute of Tyche, alluding to luck (which is also found in Roman times in the form of Tyche/Fortuna pendants), while the life cycle of the cicada, believed to be born from the earth, could ensure a harmonious transition from the status of parthenos to that of gynê, the married woman who has borne a child.$^{86}$

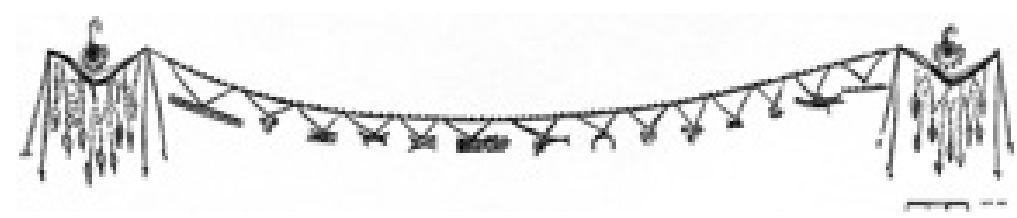

6 Black-glaze Pyxis. Benaki Museum. Line-drawing

\section{CONCLUSION}

The elusive nature of the evidence for amuletic charms, drawn as it is from literary, iconographic and archaeological sources, with their different biases and shortcomings, demands circumspection.

On Greek vase-painting and in statuary, for example, most depictions show boys with amulet cords and very few girls, ${ }^{87}$ whereas most of the relevant archaeological evidence come from girls' graves. Such iconography may focus on boys because amulets were a device to indicate their legitimate status and thus relevant to an event that marked their entry into social life. Martine Seifert has recently suggested that, at any rate at Athens, they received the amulets after being introduced by the

86 Kallintzi/Papaikonomou 2006, 483.

87 See e.g. the children, mainly boys, on choai; Neils/Oakley 2003, cat. 96, 99 with bibliography. 
father to the phratry at the Apatouria, a festival that took place each autumn. ${ }^{88}$ However, these objects may have been given them still earlier, as is suggested by the newborn babies in swaddling clothes with chains of amulets from the Greek colony of Poseidonia, and perhaps the birth scenes of divine children with charms..$^{89}$

Virtually no text either in Greece or in Rome specifies the circumstances under which such gifts were given. Only Plautus (250-184 BC) seems to suggest that they were considered suitable as birthday presents, for in his Epidicus the hero asks Telestis: 'Don't you remember my bringing you a crescent (lunula) upon your birthday, dies natalis, and a little gold ring for your finger?'90 Small, cheap, often strange, amuletic charms offer the opportunity of discovering another side of ancient societies. Studying amulets can make an important contribution to our understanding of the place of children in ancient communities. In the context of high infant mortality, these objects attest to a close interest in the welfare of children. They can be used to infer the parents' emotional investment in the survival of neonates, and so the formation of parental bonding. Some shapes and material correspond to diseases described in texts.

These objects may also transmit the traces of lost oral traditions. They may perhaps embody a memory of the 'foolish tales' told by wet-nurses about female demons that kill babies, and the protective animals, such as the hare, that substitute for our little mouse. ${ }^{91}$

PHOTO CREDITS

Figs. 1, 5 Photo S. Schenker

Fig. 2 After Schlumberger, 74 (fig.)

Fig. 3 After Brives 2008, fig. 1, no 2

Fig. 4 Photo Musées royaux d'Art et d'Histoire

Fig. 6 Line-drawing after Ziva 2009, fig. 25

88 Seifert 2011. See also the numerous temple-boys from Cyprus with amulets; Dasen 2008, pl. II, fig. 5, with earlier bibliography.

89 Ammerman 2007, 142-43, figs 7.12-7.14.

90 Plautus, Epidicus, 639-40; transl. P. Nixon (Loeb).

91 Dunham 1993, on Syrian amulets part of the tale Lamashtu, the childkiller demon, in children's graves. More on amulets, see Dasen 2015. 
PI. 7a-b Photo Claudia Wagner, Beazley Archive, Oxford University

PI. 8,9 (C) Trustees of the British Museum

PI. 10a Ministère de la Culture et de la Communication, DRAC RhôneAlpes. Photo Chr. Thioc

PI. 10b, 11a, 12 Photo S. Schenker

PI. 11b Photo 16th Ephorate of Prehistoric and Classical Antiquities

REFERENCES

Adams 1982 Adams, J. N.: The Latin Sexual Vocabulary. London 1982.

Alvar Nuño 2012 Alvar Nuño, A.: Envidia y fascinación. El mal de ojo en el Occidente Romano. Huelva 2012.

Barb 1966 Barb, A. A.: Antaura: The Mermaid and the Devil's Grandmother. In: Journal of the Warburg and Courtauld Institutes 29 (1966) 1-23.

Bel 2012 Bel, V.: Les dépôts de mobilier dans les tombes d'enfants et d'adolescents en Gaule Narbonnaise au Haut-Empire. In: A. Hermary and C. Dubois (eds), L'enfant et la mort dans l'Antiquité III, Le matériel associé aux tombes d'enfants. Paris/Aix-en-Provence 2012, 193-216.

Bernand 1991 Bernand, A.: Sorciers grecs. Paris 1991.

Bettini 1998 Bettini, M.: Nascere. Storie di donne, donnole, madri ed eroi. Torino 1998 .

Bieber 1915 Bieber, M.: Die antiken Skulpturen und Bronzen des königl. Museum Fridericianum in Cassel. Marburg 1915.

Brives 2008 Brives, A.-L.: Une inhumation d'enfant privilégiée du CentreOuest de la Gaule: la sépulture 343 de la nécropole des Dunes à Poitiers (Vienne). In: Antiquités Nationales 39 (2008) 168-71.

Carè 2012 Carè, B.: L'astragalo in tomba nel mondo greco: un indicatore infantile? Vecchi problemi e nuove osservazioni a proposito di un aspetto del costume funerario. In: A. Hermary and C. Dubois (eds), L'enfant et la mort dans l'Antiquité III, Le matériel associé aux tombes d'enfants. Paris/ Aix-en-Provence 2012, 403-16.

Causey 2011 Causey F.: Amber and the Ancient World. Los Angeles 2011.

Clerc 1995 Clerc J.-B.: Homines magici: étude sur la sorcellerie et la magie dans la société romaine impériale. Bern 1995.

Bruneau 1964 Bruneau, Ph.: Apotropaia déliens. La massue d'Héraclès. In: BCH 88 (1964) 159-68. 
Castella 1999 Castella D. et al.: La nécropole gallo-romaine d'Avenches "En Chaplix", II. Lausanne 1999.

Clarke 2007 Clarke, J.: Looking at Laughter: Humor, Power, and transgression in Roman Visual Culture, 100 B.C. - A.D 250. Berkeley 2007.

Cusumano 2008 Cusumano, N.: Ad infantes terrendos. Sortilegi e disordine metamorfico nell'immaginario mitico greco sull'infanzia. In: I. E. Buttitta (ed.): Miti Mediterranei. Atti del Convegno internazionale. Palermo 2008, 47-65.

Daniel/Maltomini 1990-92 Daniel R. W. and Maltomini F. (eds), Supplementum Magicum I and II. Opladen 1990-92.

Dasen 2003 Dasen, V.: Amulettes d'enfants dans le monde grec et romain. In: Latomus 62 (2003) 275-89.

Dasen 2008 Dasen, V: Le secret d'Omphale. In: Revue archéologique 2008, 265-81.

Dasen 2009a Dasen, V.: Empreintes maternelles. In: La madre/ The mother. Firenze 2009, 35-54.

Dasen 2009b Dasen, V.: Une 'Baubô' sur une gemme magique. In: L. Bodiou et al. (eds), Chemin faisant. Mythes, cultes et société en Grèce ancienne. Mélanges en l'honneur de Pierre Brulé. Rennes 2009, 271-84.

Dasen 2011 Dasen, V.: Magic and Medicine: the Power of Seals. In: Chr. Entwistle and N. Adams (eds): 'Gems of Heaven'. Recent Research on Engraved Gemstones in Late Antiquity c. AD 200-600. London 2011, 69-74.

Dasen 2015 Dasen, V.: Le sourire d'Omphale. Maternité et petite enfance dans l'Antiquité. Rennes 2015.

Dasen, in press Dasen, V.: Iconographie et archéologie des rites de passage de la petite enfance dans le monde romain. Questions méthodologiques. In: A. Mouton and J. Patrier (eds), Life, Death, and Coming of Age in Antiquity: Individual Rites of Passage in the Ancient Near East and its Surroundings / Vivre, grandir et mourir dans l'antiquité: rites de passage individuels au Proche-Orient ancien et ses environs. Leiden 2015, in press.

Dölger 1934 Dölger, F.: Das Apollobildchen von Delphi als Kriegsamulett des Sulla. In: Antike und Christentum 4 (1934) 67-73.

Dunbabin/Dickie 1983 Dunbabin, K. and Dickie, M.: Invida Rumpantur Pectora: The Iconography of Phthonos/Invidia in Graeco-Roman Art. Jahrbuch für Antike und Christentum 26 (1983) 7-37.

Engemann 1975 Engemann, J.: Zur Verbreitung der magischen Übelabwehr in der nichtchristlichen und christlichen Spätantike. Jahrbuch für Antike und Christentum 18 (1975) 22-49. 
Faraone 2012 Faraone, C. A.: Vanishing Acts on Ancient Greek Amulets: from Oral Performance to Visual Design. London 2012.

Gaillard-Seux 1998 Gaillard-Seux, P.: Les maladies des yeux et le lézard vert. In: G. Sabbah (ed.), Nommer la maladie. Recherches sur le lexique grécolatin de la pathologie. Saint-Etienne 1998, 93-105.

Gaillard-Seux 2013 Gaillard-Seux, P.: Traitement magique des maux de dents à l'époque romaine impériale (Ier-Ve siècles). In: F. Collard and E. Sammama (eds), Dents, dentistes et art dentaire: Histoire, pratiques et représentations - Antiquité, Moyen Age, Ancien Régime. Paris 2013, 191-210.

Goette 1986 Goette, H. R.: Die Bulla. In: Bonner Jahrbücher 186 (1986) 133-64.

Heim 1892 Heim, R. L. M.: Incantamenta magica graeca latina. Jahrbuch für classische Philologie, Supplementband, 19 (1892) 465-575. Also as separatum, Leipzig 1892.

Herrmann/Staubli 2010 Herrmann, Chr. and Staubli, Th.: 1001 Amulett. Altägyptischer Zauber, monotheisierte Talismane, säkulare Magie. Freiburg 2010.

Ilani et al. 1999 Ilani, Sh. et al.: Mineralogy and Chemistry of a Roman Remedy from Judea, Israel. In: Journal of Archaeological Science 26 (1999) 1323-26.

Jeammet 2011 Jeammet, V.: Petite plastique, grands maux. In: L. Bodiou et al. (eds), Corps outragés, corps ravagés de l'antiquité au Moyen Âge. Turnhout 2011, 39-82.

Jelski 1984 Jelski, G.: Pendentifs phalliques, clochettes et peltae dans les tombes d'enfants. In: Revue du Nord 66 (1984) 260-79.

Johns 1982 Johns, C.: Sex or Symbols? Erotic Images of Greece and Rome. London 1982.

Johnston 1995 Johnston, S. I.: Defining the Dreadful: Remarks on the Greek Child-Killing Demon. In: M. Meyer and P. Mirecki (eds), Ancient Magic and Ritual Power. Leiden 1995, 361-87.

Kallintzi/Papaikonomou 2006 Kallintzi, K. and Papaikonomou, I.-D.: A Methodical Approach to Funeral Goods Offered to Children in Ancient Abdera, in C. Mattusch et al. eds, Common Ground: Archaeology, Art, Science, and Humanities: Oxford 2006, 480-84.

Keyssner 1936 Keyssner, K.: s.v. Nodus. In: RE 17.1 (1936) 803-09.

Kotansky 1994 Kotansky, R. D.: Greek Magical Amulets: The Inscribed Gold, Silver, Copper, and Bronze Lamellae, Part I: Published Texts of Known Provenance. Opladen 1994. 
Kreilinger 2007 Kreilinger, U.: Anständige Nackheit. Körperpflege, Reinigungsriten und das Phänomen weiblicher Nackheit im archaisch-klassischen Athen. Rhaden/Westf. 2007.

Levi 1947 Levi, D.: Antioch Mosaic Pavements. Princeton 1947.

Merkouri 2010 Merkouri, Ch.: Baskanos ophthalmos. Symbola mageias apo idiotikes archaiologikes sylloges. Athens 2010.

De Meester de Ravestein 1884 E. de Meester de Ravestein, Musée Ravestein, Notice. Brussels $1884^{2}$.

Loux 1981 Loux, F.: L'ogre et la dent. Paris 1981.

Nagy 1992 Nagy, A. M.: EUPOLI EUTUCI. Bulletin du Musée Hongrois des Beaux-Arts 76 (1992) 15-29.

Neils/0akley 2003 Neils, J. and Oakley, J. H. (eds): Coming of Age in Ancient Greece, Images of Childhood from the Classical Past. New Haven 2003.

Nock 1931/1972 Nock, A. D., The Lizard in Magic and Religion. In: Z. Stewart (ed.), Essays on Religion and the Ancient World, 2 vols. Oxford 1972, 1.271-6. (Repr. from Bell, H. I., Nock, A. D., and Thompson, H.: Magical Texts from a Bilingual Papyrus in the British Museum. ProcBritAcad 17 (1931) 235-87. Also as a separatum, London 1932.

Palmer 1989 Palmer, R. E. A.: Bullae insignia ingenuitatis. In: American Journal of Ancient History 14 (1989) 1-69.

Papaikonomou 2006 Papaikonomou I. D.: Linterprétation des 'jouets' trouvés dans les tombes d'enfants d'Abdère. In: A.-M. Guimier-Sorbets et al. (eds). Rois, cités, necropolis. Institutions, rites et monuments en Macédoine. Athènes 2006, 239-49.

Patera 2005 Patera, M.: Comment effrayer les enfants: le cas de Mormô/ Mormolukê et du mormolukeion. Kernos 18 (2005) 371-90.

Péchoux 2010 Péchoux, L.: De l'enfance à l'âge adulte: recherche de preuves matérielles de rites de passage en Gaule romaine. In: P. Hameau (ed.), Les rites de passage, de la Grèce d'Homère à notre XXIe siècle. Isère 2010, 25-38.

Rakoczy 1996 Rakoczy, Th.: Böser Blick, Macht des Auges und Neid der Götter: eine Untersuchung zur Kraft des Blickes in der griechischen Literatur. Tübingen 1996.

Saglio 1906 Saglio, E.: s.v. Nodus. In: Ch. Daremberg and E. Saglio (eds), Dictionnaire des antiquités grecques et romaines, IV/1. Paris 1906, 87-88.

Schlumberger 1892 Schlumberger, G.: Amulettes byzantins anciens destinés à combattre les maléfices \& maladies. In: Revue des études grecques 5 (1892) 73-93. 
Seifert 2011 Seifert, M.: Dazugehören. Kinder in griechischen Kulten und Festen von Oikos und Phratrie. Bildanalysen zu attischen Sozialisationsstufen des 6. bis 4. Jahrhunderts v. Chr. Stuttgart 2011.

Sgourou/Agelarakis 2001 Sgourou, M. and Agelarakis, A. P.: Jewellery from Thasian Graves. In: Annual of the British School at Athens 96 (2001) 327-64.

Slane/Dickie 1983 Slane K. W. and Dickie M. W., A Knidian Phallic Vase from Corinth. In: Hesperia 62 (1993) 483-505.

Sorlin 1991 Sorlin, I.: Striges et Geloudes. Histoire d'une croyance et d'une tradition. In: Travaux et Mémoires. Centre de recherche d'histoire et de civilisation byzantine 11 1991, 411-36.

Spier 1993 Spier, J.: Medieval Byzantine Magical Amulets and their Tradition. In: Journal of the Warburg and Courtauld Institutes 56 (1993) 25-62.

Swift 2003 Swift, E.: Late-Roman Bead Necklaces and Bracelets. In: JRS 16 (2003) 336-49.

Szilágyi 2004 Szilágyi, M.: The Meaning and Use of Bullae in Late Classical Pannonia in their Imperial Context. Budapest 2004, unpublished MA.

Werner 1964 Werner, J.: Herkuleskeulen und Donar-Amulett. In: Jahrbuch des Römisch-Germanischen Zentralmuseums Mainz 11 (1964) 176-97.

Wolters 1905 Wolters, P.: Faden und Knoten als Amulett. Archiv für Religionswissenschaft 8 (1905) 1-22.

Wrede 1975 Wrede, H.: Lunulae im Halsschmuck. In: I. Scheibler and H. Wrede (eds), Wandlungen. Studien zur antiken und neueren Kunst. Festschrift für E. Homann-Wedeking. Waldsassen 1975, 243-54.

Ziva 2009 Ziva, A.: Untimely Death: the Symbolism of the Imagery on a Black-Glaze Pyxis from the Benaki Museum Collection (in Greek). In: Mouseio Benaki 9 (2009) 21-43. 


\section{PLATES}



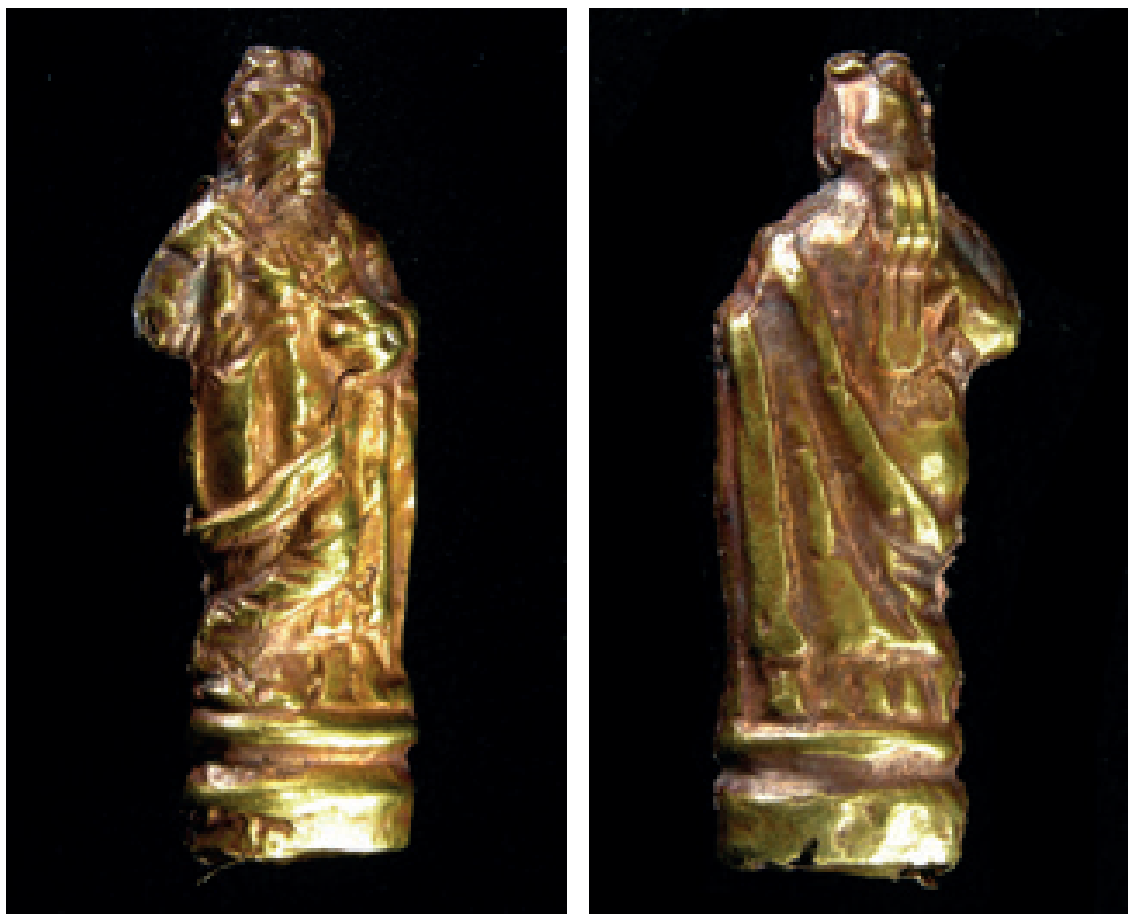

7a-b Gold (H. 3,95 cm). Derek Content Collection 19 


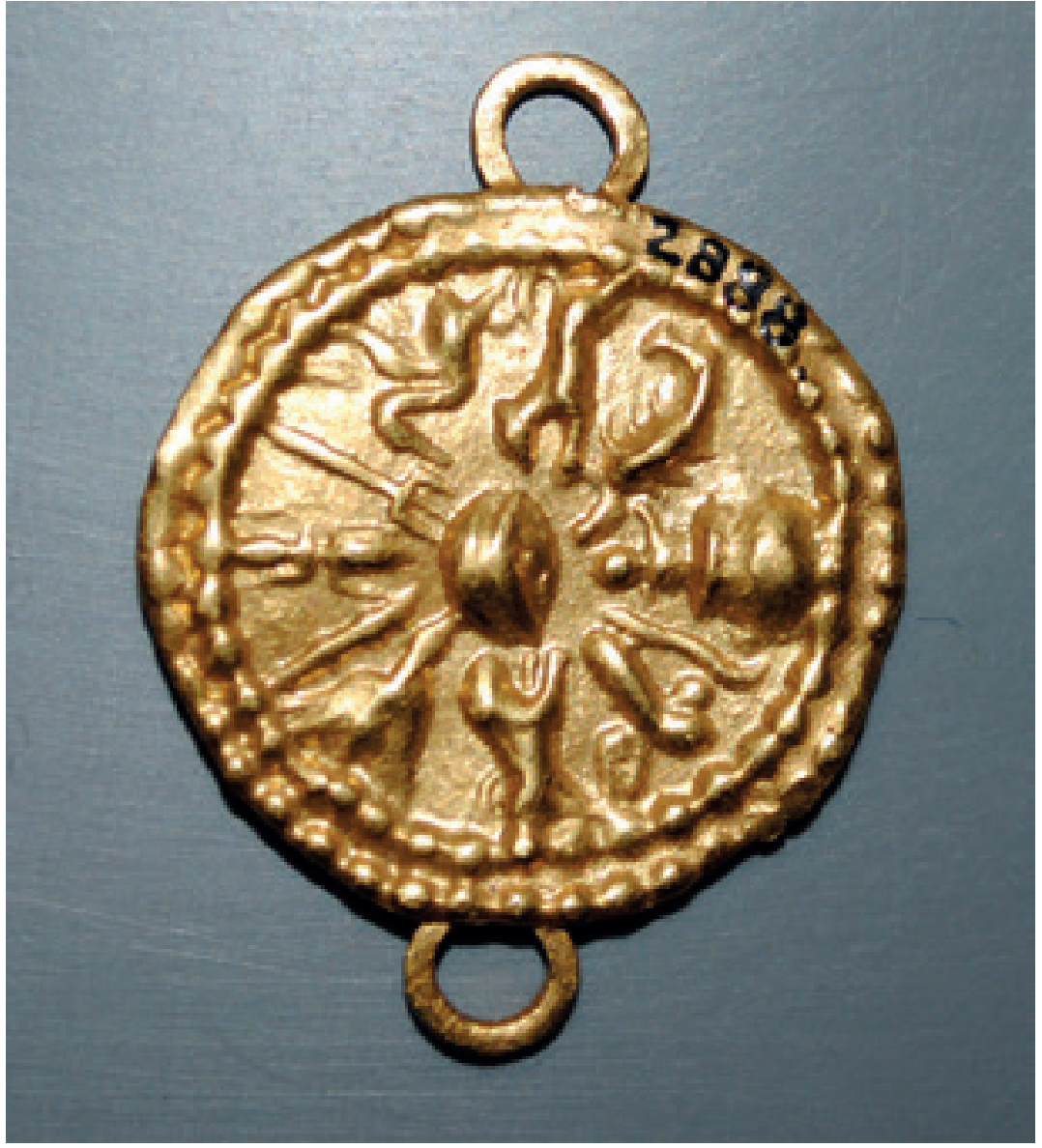

8 Gold (H. 3,5 cm). London, British Museum 1895,1025.4 


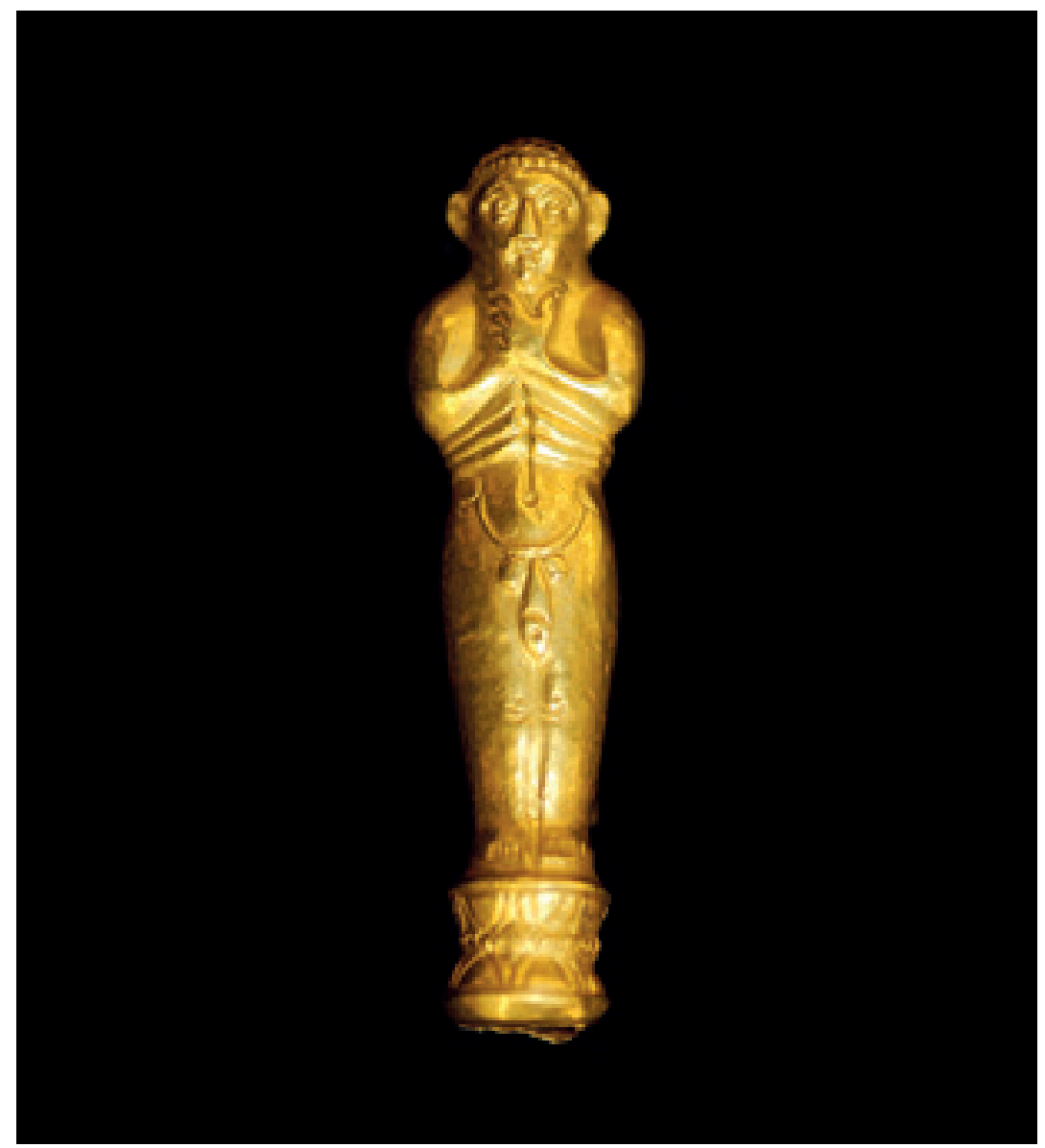

9 Gold (diam. 2 cm). London, British Museum 1814,0704.1172 


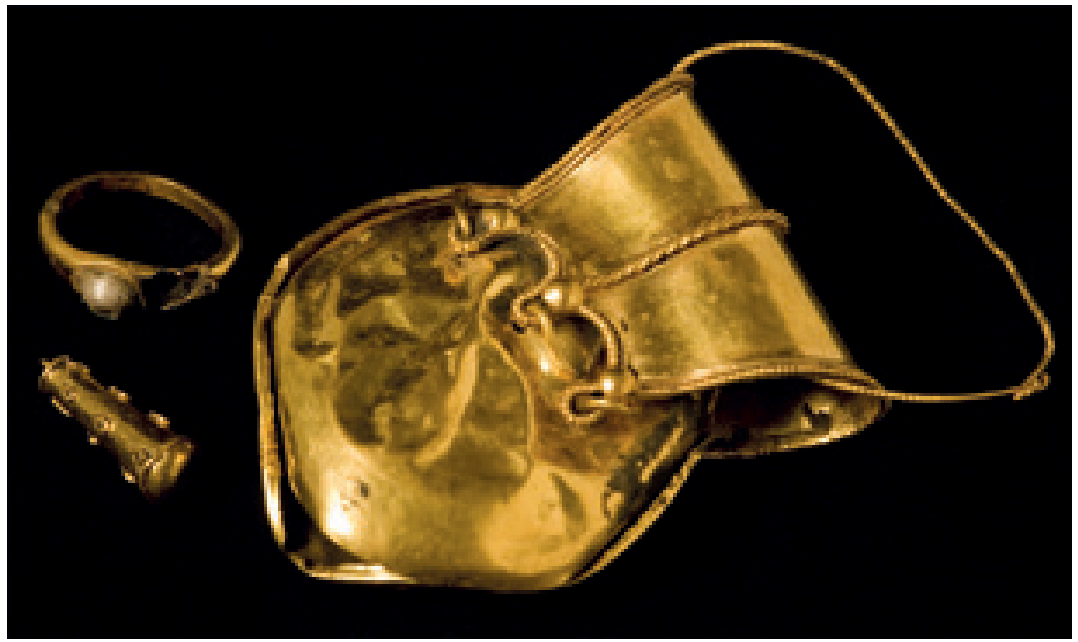

10a Gold bulla (L. 3,8 $\times 5,3 \mathrm{~cm}$ ) and gold club pendant (L. 1,8 cm). Ministère de la Culture et de la Communication, DRAC Rhône-Alpes

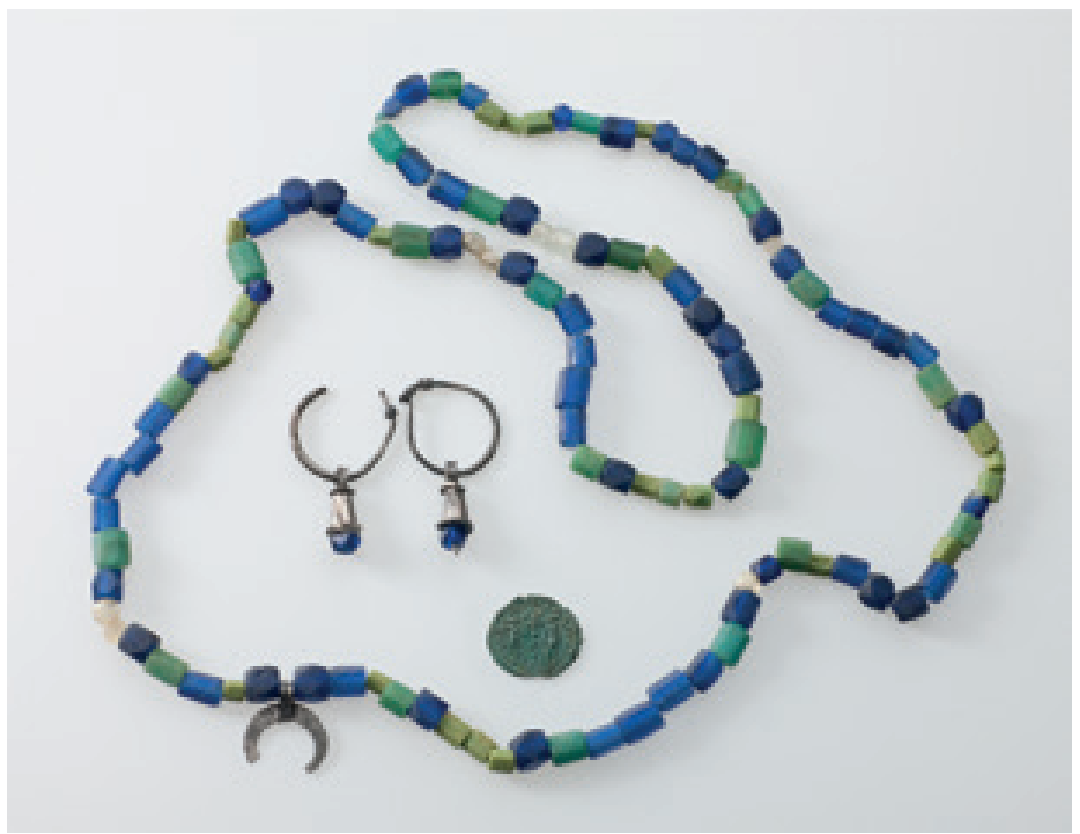

10b Glass beads necklace with a silver lunula $(\mathrm{H} .1,6 \mathrm{~cm})$ and two silver earrings (H. $3,5 \mathrm{~cm}$ ). Augusta Raurica 


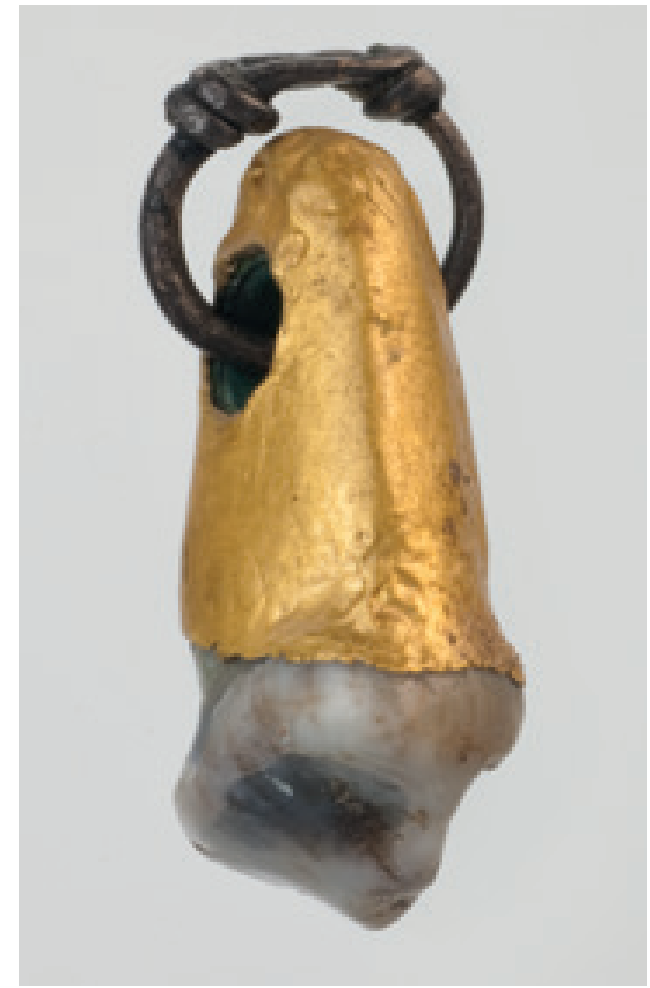

11a Lion tooth (H. $2,3 \mathrm{~cm})$. Augusta Raurica 1959.2588

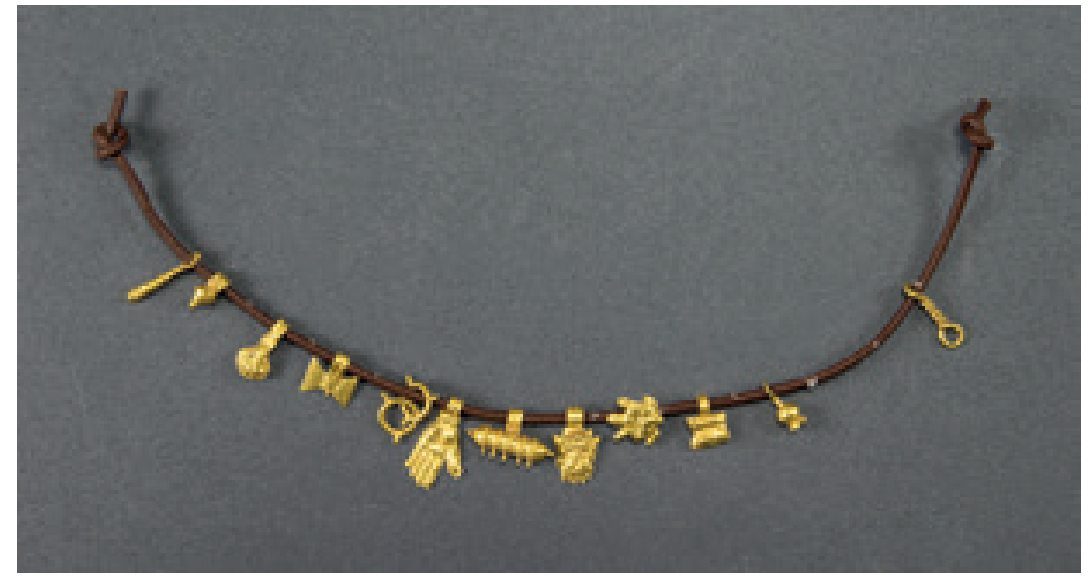

11b Gold charms. Polygyros, Archaeological Museum MT 7468 


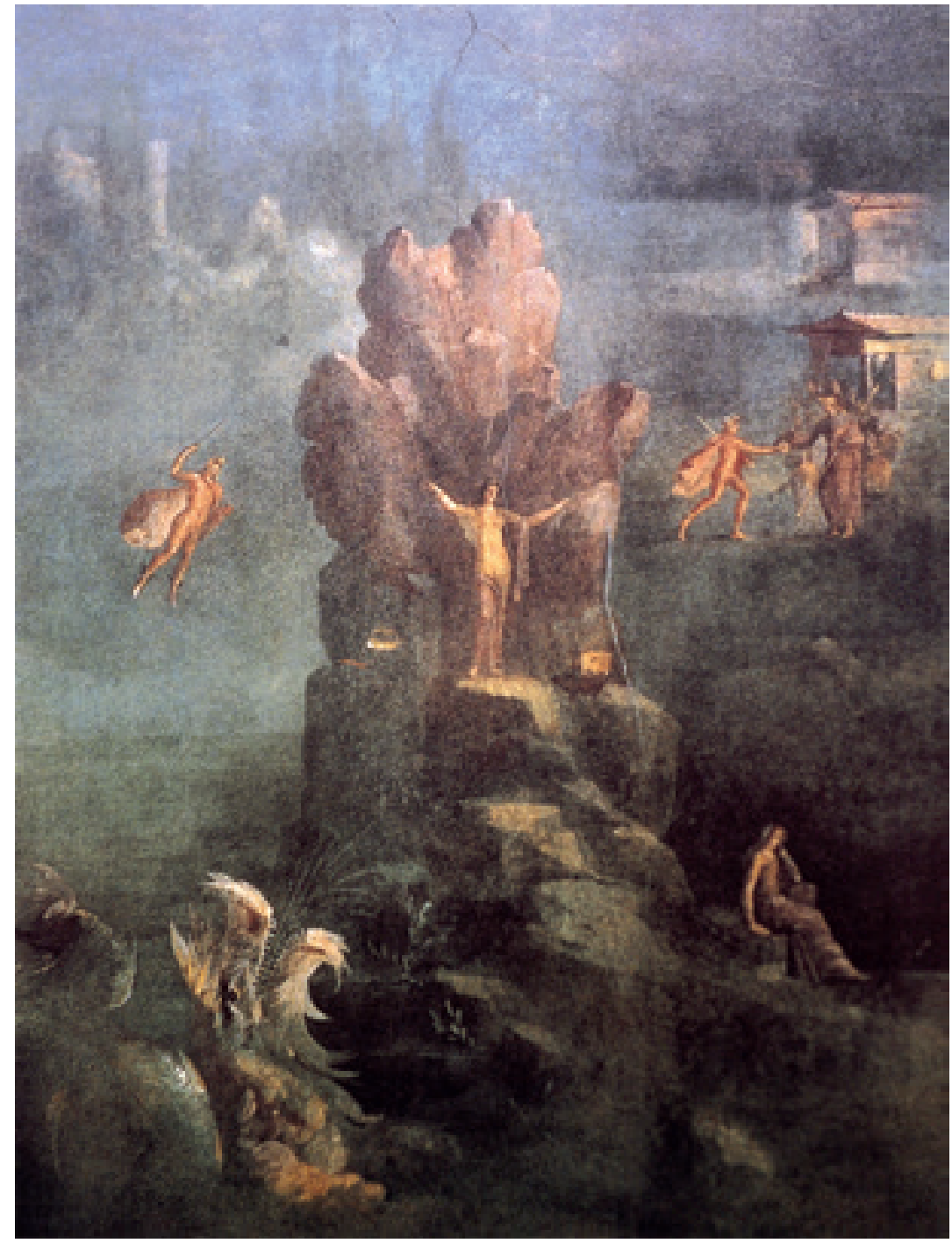

12 Fresco with Perseus and Andromeda. From the villa of Agrippa Postumus at Boscotrecase. New York, Metropolitan Museum, inv. no. 20.192.16 